\title{
NUTRITIONAL EVALUATION OF PATTIES FORTIFIED WITH SOME NATURAL SOURCES RICH IN IRON
}

\author{
El-Bana, M.A.*; Sahar R. Abd El-Hady ** and Zein, Ragaa I. ${ }^{\star *}$ \\ * Food Tech. Res. Inst. Agric. Res. Center Giza, Egypt \\ ** Food Sci. and Tech. Dept. Fac. of Agric. Kafr El-Sheikh Univ., Egypt
}

\begin{abstract}
The current investigation aimed to study the possibility of preparation some kinds of patties high in their content of iron using food sources rich in iron. In this matter cooked minced beef muscles as animal sources, cooked spinach as plant sources. These ingredients were used as stuff of patties. Defatted soybean and black rice flours were used at level of $5 \%$ to prepare some non stuffed patties rich in iron. Chemical composition and iron content of raw materials and the prepared patties were determined. Sensory properties of prepared patties were evaluated.

Concerning protein quality, the amino acids composition, chemical score, computed protein efficiency ratio (PER) and Biological value (B.V.) of prepared patties were calculated.

The obtained results show that the patty stuffed with minced cooked beef was superior in its content of iron and protein than the other patties. Sensory evaluation proved that all prepared patties had a good acceptability especially the stuffed patties. Higher amount of indispensable amino acids, were found in all patties fortified with defatted soybean flour and the patty stuffed with mix of cooked minced beef and cooked spinach. In this relation, the patty stuffed with minced beef were found to contain the highest amount of indispensable AA. In addition, the patty stuffed with cooked minced beef had the higher amino acid scores, computed protein efficiency ratio (C-PER) and biological value (B.V.) compared to the other types of patties.
\end{abstract}

\section{INTRODUCTION}

Iron deficiency anemia is currently the most frequent nutritional disorder worldwide, in different countries which being affected to a different extent. Iron deficiency is estimated to affect more than $20 \%$ of the world population (International Nutritional Anemia Consultative Groups, 1998, Marinez-Navarrete et al., 2002 and Sawnson, 2003). Iron is a major component of haemoglobin that carries oxygen to all parts of the body. Iron has also a critical role within cells assisting in oxygen utilization, enzymatic system, especially for neutral development and overall cell function everywhere in the body (Alton, 2005 and Bersamin, 2004).

Gerrior and Bente (2001) stated that iron levels in the food supply increased from $15.3 \mathrm{mg}$ per person per day in 1970 to $23.6 \mathrm{mg}$ per person per day in 1999. Grains and breakfast cereals provided 35 percent of iron in the food supply in 1970 and 53 percent in 1999. Meat, poultry, fish and meat alternates provided 32 percent of iron in the food supply in 1970 and 23 percent in 1999. Enriched grains and fortified ready to eat breakfast cereals contributed to the incase in grains and cereals as a source of iron.

In Egypt, anemia prevalence among preschool children is $40 \%$ (Anonymous, 1991 and Abd Rabou, 1994). The information published in Egypt by National Nutrition Surveys (1978-1980) revealed that iron deficiency 
anemia in Egypt is principal due to malnutrition especially insufficient available iron where, $14 \%$ of pregnant women and women who breast fed also $52 \%$ of children used to get less than $75 \%$ of recommended daily allowances (RDA) of iron. So, food fortified with iron is generally considered the most effective way to increase iron intake and can be achieved by fortifying widely consumed foodstuffs which provide iron to all segments of the population.

Iron, zinc and calcium can interact with each other in a way that inhibits their respective absorption. On the other hand, mineral fortification has been used to improve simultaneous iron and zinc absorption from food supplements (Mendoza et al., 2004).

Reduced iron and several iron salts had been used as iron fortification. However, there are many problems concerning the choice of the iron salt suitable to achieve this purpose in the food products. Moreover, about $8 \%$ patients on iron therapy have side effects, ranging from nausea and vomiting to diarrhea and severe stomach cramps. It is sometimes suggested that other iron salts may be less toxic than ferrous sulfate (Ree and Monsen, 1973 and Bothwell et al., 1979). Recently, Lund et al. (1999) found that oral ferrous sulfate supplements increase in the free radicalgenerating capacity of feces from healthy volunteers. In contrast, there are insufficient studies about the potential use of the natural sources of dietary iron in fortification of backed products.

The type of cereal grain has little influence on iron bioavailability of infant cereals. On the other hand, modification in the milling and processing methods for cereal gains that reduce their content of phytic acid is likely to improve iron availability significantly (Cook et al., 1997).

Small amount of meat $(\geq 50 \mathrm{~g})$ significantly increase non heme-iron absorption from a phytate-rich meal low in vitamin C (Bach et al., 2003).

The Peruvian government is currently providing preschool children (3-36 months of age) with a precooked food supplement prepared from a mix of cereals, defatted soybean flour, and dried milk fortified with vitamins and minerals added in amounts equal to $100 \%$ of the recommended dietary allowances for vitamin A, vitamin C, iron, zinc and iodine, $60 \%$ of the recommended dietary allowances for thiamin, niacin, folic acid, riboflavin, vitamin B-6 vitamin B-12 and magnesium (Gibson et al., 1998).

According, this work was carried out to prepare some patties fortified with natural sources rich in iron such as cooked miced beef muscles, cooked spinach, defatted soybean and black rice flours. These fortified patties were chemically, organoleptically and protein quality evaluated.

Materials:

\section{MATERIALS AND METHODS}

Wheat flour (72\% extraction) was obtained from the Middle Delta Flour Mills Company. Defatted soybean flour obtained from soy products factory of Food Technology Research Institute, Agricultural Research Center, Giza, Egypt. Black rice obtained from the Rice Research and Training Center (RRTC), Sakha, Kafr El-Sheikh Governorate, Egypt. 
Other ingredients used in making patties included minced beef muscles, eggs, shortening, sunflower oil, dry milk, compressed yeast, sugar, salt and spinach were purchased from local market at Kafr El-Sheikh, Egypt.

\section{Methods:}

Technological methods:

Preparation of different stuff blends:

Preparation of stuff blends used to fill the patties were done by adding and mixing of all ingredients $(500 \mathrm{~g}$ minced beef muscles or 1 kilogram fresh and washed spinach $+200 \mathrm{gm}$ minced onion $+5.0 \mathrm{gm}$ sunflower oil $+5.0 \mathrm{gm}$ salt and species), then cooked on direct heat until the mixture appears to be moisture free and fully cooked.

\section{Patties making:}

Patties were prepared using the method of Arora (1983). The ingredients and different blends used for making dough are shown in Table (1).

Table (1): Ingredients and blends used for making patties (gm on wet basis).

\begin{tabular}{|l|c|c|c|}
\hline \multirow{2}{*}{\multicolumn{1}{|c|}{ Ingredients }} & \multicolumn{3}{c|}{ Blends for non stuffed patties } \\
\cline { 2 - 4 } & 1 & 2 & 3 \\
\hline Wheat flour 72\% extraction & 100 & 95 & 95 \\
Defatted soybean flour & - & 5 & - \\
Black rice flour & - & - & 5 \\
Shortening and sunflower oil & 17 & 17 & 17 \\
Egg & 20 & 20 & 20 \\
Dry milk & 5 & 5 & 5 \\
Compressed yeast & 6 & 6 & 6 \\
Sugar & 13 & 13 & 13 \\
Salt & 2 & 2 & 2 \\
Water & 25 & 25 & 25 \\
\hline
\end{tabular}

The ingredients of each blend were good mixed together and left at room temperature to ferment, then small pieces of required weight $(100 \mathrm{gm})$ to use without stuffing and $(70 \mathrm{gm})$ for patties which will be stuffed with the prepared stuff blends were cut off from the prepared dough. These pieces were rounded and fermented for $15 \mathrm{~min}$. Then the pieces weight $70 \mathrm{gm}$ were stuffed with the different stuff blends as shown in Table (2).

Table (2): Types of patties stuffed with different prepared stuff blends (gm. wet basis).

\begin{tabular}{|l|c|c|c|}
\hline \multirow{2}{*}{\multicolumn{1}{|c|}{ Ingredients }} & \multicolumn{3}{c|}{ Types of stuff patties } \\
\cline { 2 - 4 } & 4 & 5 & 6 \\
\hline Dough from blend No. 1 & $70 \mathrm{gm}$ & $70 \mathrm{gm}$ & $70 \mathrm{gm}$ \\
Cooked minced beef mix & $30 \mathrm{gm}$ & - & $15 \mathrm{gm}$ \\
Cooked spinach mix & - & $30 \mathrm{gm}$ & $15 \mathrm{gm}$ \\
\hline
\end{tabular}


The prepared patties were left to rest for $15 \mathrm{~min}$, then baked in electrical oven at $220-240^{\circ} \mathrm{C}$ for 20 to $25 \mathrm{~min}$., then cooled to room temperature.

The backed patties were packaged in polyethylene bags and divided into two parts as follows:

The first part, was used to evaluate the organoleptic properties of the patties. The second part, was stored at $-18 \pm 2^{\circ} \mathrm{C}$, for chemical analysis.

\section{Sensory evaluation:}

The organoletpic properties of the prepared patties were evaluated by ten panelists for various quality (texture, color, taste, odor and overall acceptability). The evaluation were made using scores from 1 to 10 , where excellent (10-9), very good (8-6), fair (5-4) and not acceptable (3-2) according to the method described by Renzo (1975).

\section{Chemical analysis:}

Proximate chemical composition including moisture, crude protein, ether extract, crude fiber and ash of the raw materials and prepared patties were determined according to the methods of A.O.A.C. (1990). Carbohydrates content was calculated by difference. Minerals were determined using atomic absorption spectrophotometer (Perben Elmer Model 2180) as described by A.O.A.C. (1990). All samples were analyzed in triplicates.

\section{Nutritional evaluation:}

Amino acids determination: samples of studied patties were subjected to acid hydrolysis using $6 \mathrm{~N} \mathrm{HCl}$ and few drops of mercaptoethanol. The hydrolyzate was recovered by removing the acid by evaporating in a rotary evaporator. Amino acids were estimated in the hydrolyzate using amino acid analyzer (Beckman amino acid analyzer, Model $119 \mathrm{CL}$ ) as described by Sadasivam and Manickam (1992) method. Tryptophan was determined colorimetrically after alkaline hydrolysis of sample as outlined by Miller (1967). Chemical score of indispensable amino acids was calculated using the equations of Pellet and Young (1980). Computation procedure for protein efficiency ratio (C-PER) of different studied patties was calculated as described by Alsmeyer et al. (1974) using following equation:

$\mathrm{C}-\mathrm{PER}=-1.816+0.435$ (Methionine) +0.780 (leucine) +0.211 (histidine) 0.944 (tyrosine). Biological values were calculated using the following equation reported by Farag et al. (1996):

Biological value (B.V.) $=49.9+10.53$ C-PER, Where C-Per $=$ computed protein efficiency ratio.

\section{Statistical analysis:}

The data were statistically analyzed using the analysis of variance and the means were further tested using the least significant difference test as outlined by Steel and Torrie (1980). 


\section{RESULTS AND DISCUSSION \\ Chemical composition of raw materials:}

Chemical composition of raw materials presented in Table (3) show that, beef muscles had the highest protein content (78.62\%) followed by defatted soy flour (47.93\%). These results are coinciding with those reported by Park et al. (1996), Kassab (1999), Hamza (1999) and Khalil (2003). Beef muscle had the highest fat content (14.45\%) compared with the other raw materials. The highest carbohydrates content was found in black rice (89.61) compared with defatted soybean flour which had the lowest content $(42.91 \%)$. The results also showed that spinach had the highest fiber content (16.51\%). The results in the same table showed that spinach had highest contents of ash and iron compared with those of wheat flour. The highest iron content was found in black rice followed by spinach, beef muscle then defatted soybean. Their values were 43.8, 26.74, 18.0 and $8.93 \%$, respectively, while wheat flour ( $72 \%$ extraction) had the lowest content of iron. The aforementioned results coincide with those obtained by Nour et al. (1983), Farrell (1990), Millgi et al. (2000), Abd El-Rahim et al. (2001) and ElBadawi et al. (2003).

Table (3): Chemical composition of raw materials used for prepared of studied patties $(\mathrm{gm} / 100 \mathrm{~g}$ on dry weight basis.

\begin{tabular}{|l|c|c|c|c|c|c|c|}
\hline \multicolumn{1}{|c|}{ Raw materials } & Moisture & $\begin{array}{c}\text { Crude } \\
\text { protein }\end{array}$ & $\begin{array}{c}\text { Crude } \\
\text { fat }\end{array}$ & Ash & Carbohydrates * & $\begin{array}{c}\text { Crude } \\
\text { fiber }\end{array}$ & $\begin{array}{c}\text { Iron } \\
\text { mg/100 gm }\end{array}$ \\
\hline Wheat flour & 11.22 & 10.16 & 1.23 & 0.72 & 87.89 & 0.78 & 1.82 \\
Defatted soybean flour & 8.34 & 47.93 & 2.91 & 6.25 & 42.91 & 4.77 & 8.93 \\
Black rice flour & 12.31 & 8.51 & 0.71 & 0.76 & 89.61 & 0.41 & 43.8 \\
Beef muscle & 71.22 & 78.62 & 14.45 & 4.93 & - & - & 18.0 \\
Spinach & 91.55 & 31.38 & 3.75 & 20.24 & 44.63 & 16.51 & 26.74 \\
\hline
\end{tabular}

* Calculated by difference

\section{Chemical composition of different prepared patties:}

Data presented in Table (4) show the chemical composition of the prepared patties. The results indicate that slight increase in protein, crude fat, ash, fiber and iron content of patties contained $5 \%$ soybean flour (No. 2) compared with patties (No. 1) which contained $100 \%$ wheat flour. These results may be due to composition of defatted soy flour which contained $47.93 \%$ crude protein, $2.91 \%$ fat, $6.25 \%$ ash, $4.77 \%$ fiber and $8.93 \mathrm{mg}$ iron/100 $\mathrm{gm}$ as reported in Table (3) and coinciding with the results obtained by Abd El-Lateef (2002) and Khalil and Hussein (2002).

Comparing the chemical composition of non stuffed patties (No. 1, No. 2 and No. 3) with the stuffed patties (No. 4, No. 5 and No. 6) the results in Table (4) showed that patties stuffed with cooked beef (No. 4) and patties stuffed with blend of cooked beef and cooked spinach (No. 6) were superior in protein and fat than the others. These results are in agreement with those obtain by Cross et al. (1980), who found that, fat content of beef patties was $17.2-16.4 \%$, but Spadaro and Keeton (1996), reported that beef patties 
contained $24.50 \%$ fat, $15.91 \%$ protein while, El-Demiry (2005) found that patties stuffed with minced beef contained $21.40 \%$ protein, $16.60 \%$ fat, $3.75 \%$ ash, $2.64 \%$ fiber and $55.61 \%$ carbohydrates. On the other hand, patties stuffed with cooked spinach had the highest value of moisture, ash and iron. These results are in the same trend with those found by El-Said (2001), who indicted that spinach patties contained $9.95 \%$ fat, $12.37 \%$ protein, $2.58 \%$ ash and $2.06 \mathrm{mg} / 100 \mathrm{gm}$ iron. From the same Table (4), it is obvious that, patties contained $5 \%$ black rice (No. 3 ) had the highest content of carbohydrates and the lowest content of protein, fat and ash among all the types of patties and the highest iron between the non stuffed patties. This may be attributed to its low protein, fat and ash contents $(8.51,0.71$ and $0.76 \%$, respectively) as shown in Table (3).

Table (4): Chemical composition of the prepared patties (gm/100 gm on dry weight basis).

\begin{tabular}{|c|c|c|c|c|c|c|c|c|}
\hline Samples & Moisture & $\begin{array}{l}\text { Crude } \\
\text { protein }\end{array}$ & $\begin{array}{c}\text { Crude } \\
\text { fat }\end{array}$ & Ash & Carbohydrates* & $\begin{array}{l}\text { Crude } \\
\text { fiber }\end{array}$ & \begin{tabular}{|c|} 
Iron \\
$\mathrm{mg} /$ \\
$100 \mathrm{gm}$
\end{tabular} & $\begin{array}{c}\mathrm{Kcal} / \\
100 \mathrm{gm}\end{array}$ \\
\hline \multicolumn{9}{|l|}{ A: Non stuffed } \\
\hline No. 1 & 24.88 & 10.71 & 12.03 & 1.63 & 75.63 & 1.51 & 3.26 & 453.63 \\
\hline No. 2 & 25.79 & 12.60 & 12.54 & 2.71 & 72.15 & 2.28 & 4.51 & 451.86 \\
\hline \multicolumn{9}{|l|}{ B: Stuffed patties: } \\
\hline No. 4 & 34.32 & 20.35 & 16.20 & 4.82 & 58.63 & 1.64 & 9.52 & 461.72 \\
\hline No. 5 & 42.26 & 11.98 & 12.88 & 5.61 & 69.52 & 2.97 & 10.48 & 441.92 \\
\hline No. 6 & 39.60 & 14.25 & 13.31 & 4.43 & 68.01 & 2.08 & 8.27 & 448.83 \\
\hline \multicolumn{9}{|c|}{${ }^{*}$ Calculated by difference. } \\
\hline \multicolumn{9}{|c|}{ Patties No. 1: Prepared from $100 \%$ wheat flour (W.F.) } \\
\hline \multicolumn{9}{|c|}{ Patties No. 2: Prepared from $95 \%$ W.F. and $5 \%$ defatted soybean flour (D.S.F.). } \\
\hline \multicolumn{9}{|c|}{ 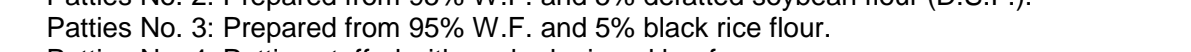 } \\
\hline \multicolumn{9}{|c|}{ Patties No. 4: Patties stuffed with cooked minced beef. } \\
\hline \multicolumn{9}{|c|}{ Patties No. 5: Patties stuffed with cooked spinach. } \\
\hline
\end{tabular}

Concerning the iron content of all types of patties, the results presented in Table (4) show that the highest iron content was found in patties stuffed with spinach $(10.48 \mathrm{gm} / \mathrm{gm})$ followed by patties stuffed with cooked beef $(9.52 \mathrm{mg} / 100 \mathrm{~g})$, while the lowest iron content was found in patties from $100 \%$ wheat flour.

The calculated energy of the prepared patties ranged between 441.92 to $461.72 \mathrm{Kcal} / 100 \mathrm{gm}$.

\section{Organoleptic evaluation of different fresh prepared patties:}

Sensory evaluation of different fresh prepared patties is presented in Table (5). It could be noticed that, all stuffed patties had higher score than the non stuffed patties. Patties stuffed with cooked beef + cooked spinach (No. 6) had the superior over all acceptability than the other types of patty. In the same time no significant differences were observed in taste, flavor and overall acceptability between the stuffed patties. The control (No. 1 (100\% wheat flour) was in the line with the stuffed patties. 
Table (5): Organoleptic evaluation of different fresh prepared patties.

\begin{tabular}{|c|c|c|c|c|c|}
\hline \multirow{2}{*}{$\begin{array}{l}\text { Types of } \\
\text { patties }\end{array}$} & \multicolumn{5}{|c|}{ Organoleptic characteristics } \\
\hline & Color & Taste & Flavor & Texture & $\begin{array}{c}\text { Overall } \\
\text { acceptability }\end{array}$ \\
\hline No. 1 & 8.35 & $8.45 a b$ & $8.30 \mathrm{ab}$ & 8.20 & $8.55 \mathrm{abc}$ \\
\hline No. 2 & 7.60 & $7.05 \mathrm{~d}$ & $6.85 c$ & 7.95 & $7.75 \mathrm{~cd}$ \\
\hline No. 3 & 7.10 & $6.95 \mathrm{~d}$ & $7.30 \mathrm{bc}$ & 8.10 & $7.50 \mathrm{~d}$ \\
\hline No. 4 & 880 & $8.70 \mathrm{a}$ & $8.70 \mathrm{a}$ & 8.75 & $8.85 \mathrm{a}$ \\
\hline No. 5 & 8.40 & $8.20 \mathrm{abc}$ & $8.60 \mathrm{a}$ & 8.20 & $8.75 \mathrm{a}$ \\
\hline No. 6 & 8.80 & $\underset{* *}{8.50} \mathrm{a}$ & $\underset{* *}{8.85} \mathrm{a}$ & 8.45 & $\underset{* *}{8.95} \mathrm{a}$ \\
\hline L.S.D. 0.05 & - & 0.95 & 0.75 & - & 0.77 \\
\hline L.S.D. 0.01 & - & 1.26 & 0.99 & - & 1.03 \\
\hline
\end{tabular}

N.S.: No significant difference at $5 \%$ level.

**: Significant difference at $1 \%$ level.

Each value is an average of ten determination.

In a column values followed by the same letter are not significantly different at the $5 \%$ level.

No. 1 , No. 2 , No. $3, \ldots$ etc. were as given in Table (4).

Worth mentioning, as reported by El-Demiry (2005) fresh baked patties could be stored in a refrigerator at $4 \pm 1^{\circ} \mathrm{C}$ for 4 days, or frozed in freezer at $-18 \pm 1^{\circ} \mathrm{C}$ for six months. The best time for heating cold and frozen stored patties for consumption was 7 and 12 minutes respectively using a conventional oven at $220^{\circ} \mathrm{C}$ to enhance their eating quality.

In conclusion the previous results of panel tests evaluation proved that all the types of patties had a good acceptability especially the stuffed patties with all different stuffings which were much more acceptable.

\section{Protein qualities of patties:}

\section{Amino acids composition:}

The amino acid requirements are the logical yard-sticks by which protein quality can be estimated and the relative quantities of the various amino acids, in particular the essential amino acids, in the food could be used as reliable estimators of actual protein quality (Alsmeyer et al., 1974).

Amino acids composition of non stuffed patties and stuffed patties are presented in Table (6). The patties samples contained all detected indispensable amino acids. It could be observed that, the stuffed patties with cooked minced beef (No. 4) and the non stuffed patties prepared from $5 \%$ defatted soybean flour (No. 2) contained the highest amount of all indispensable amino acids compared with those of other samples.

However, addition of defatted soybean flour to the wheat flour used for preparing patties resulted in an increase in their contents of sulphur containing amino acids (methionine and cystine) and this would increase the nutritive value of the food produced as reported by Infant et al. (1979).

From the results in the same table, it could be concluded that the patties prepared from wheat flour contained the lowest amount of total and individual indispensable amino acids. All patties sample contained more amount of dispensable amino acids (53.51-63.01\%) than indispensable amino acids (27.27-36.92\%). 
The nutritive value of any protein depends primarily on its capacity to satisfy the needs for indispensable amino acids for human being. Thus, the amino acid requirements are the logical factors by which protein quality can be measured (Bhushan, 1991).

Table (6): Amino acids composition of patties samples ( $\mathrm{g} / 16 \mathrm{~g} \mathrm{~N}$ ).

\begin{tabular}{|l|c|c|c|c|c|c|c|}
\hline \multicolumn{1}{|c|}{ Indispensable amino acids } & No. 1 & No. 2 & No. 3 & No. 4 & No. 5 & No. 6 & $\begin{array}{c}\text { FAO/WHO } \\
\text { pattern } \\
\text { g/16 g N }\end{array}$ \\
\hline Leucine & 5.98 & 7.11 & 6.57 & 7.38 & 6.51 & 6.65 & 7.00 \\
Isoleucine & 2.88 & 3.67 & 3.49 & 4.10 & 3.43 & 3.45 & 4.00 \\
Lysine & 2.90 & 3.75 & 2.50 & 4.41 & 2.44 & 3.21 & 5.50 \\
Methionine & 1.42 & 1.87 & 1.52 & 1.92 & 1.50 & 1.62 & \\
Cystine & 1.47 & 1.76 & 1.70 & 1.91 & 1.70 & 1.69 & \\
Methionine + cystine & 2.89 & 3.63 & 3.22 & 3.83 & 3.20 & 3.31 & 3.50 \\
Phenylaleanine & 3.81 & 4.49 & 4.29 & 4.74 & 4.22 & 4.35 & \\
Tyrosine & 2.13 & 2.66 & 2.32 & 2.95 & 2.35 & 2.31 & \\
Phenylalanine + tyrosine & 5.94 & 7.15 & 6.61 & 7.69 & 6.57 & 6.66 & 6.00 \\
Threonine & 2.21 & 2.84 & 2.28 & 3.27 & 2.46 & 2.61 & 4.0 \\
Valine & 3.53 & 4.32 & 4.21 & 4.81 & 4.10 & 4.31 & 5.00 \\
Tryptophan* & 0.94 & 1.23 & 1.20 & 1.43 & 1.16 & 1.19 & 1.00 \\
\hline Total indispensable amino acids & 27.27 & 33.70 & 30.08 & 36.92 & 29.87 & 31.4 & \\
\hline Dispensable amino acids & & & & & & & \\
\hline Alanine & 2.60 & 3.74 & 3.31 & 4.10 & 3.21 & 3.88 & \\
Arginine & 2.29 & 3.18 & 3.13 & 4.26 & 2.79 & 3.28 & \\
Aspartic acid & 4.15 & 5.5 & 5.33 & 6.4 & 5.11 & 5.82 & \\
Glutamic acid & 26.66 & 24.01 & 27.10 & 24.33 & 23.20 & 23.31 & \\
Glycine & 2.99 & 3.87 & 3.78 & 4.20 & 3.69 & 3.67 & \\
Histidine & 1.57 & 2.09 & 1.98 & 2.31 & 1.94 & 2.09 & \\
Proline & 9.38 & 11.6 & 11.37 & 11.71 & 11.67 & 11.91 & \\
Serine & 3.87 & 4.95 & 4.79 & 5.70 & 4.81 & 5.11 & \\
\hline Total dispensable amino acid & 53.51 & 58.94 & 60.79 & 63.01 & 56.46 & 59.07 & \\
\hline Total amino acids & 80.78 & 92.64 & 90.87 & 99.93 & 86.33 & 90.47 & \\
*Tryptophan was determined colourmenrically FAO/WHO (1988) \\
No. 1, No. 2, No. 3, .......etc. were as given in Table (4).
\end{tabular}

2. Amino acid scores (A.A.S.):

The amino acid scores can be considered as an imperfect indicator of protein quality, but it still is the best one based on amino acid composition (Pellett and Young, 1980).

The amino acid scores of the indispensable amino acid of non stuffed patties and stuffed patties are given in Table (7). The results revealed that, the stuffed patties with cooked minced beef (No. 4) had more amino acid scores of the indispensable amino acids than other patties. The lowest amino acids score were found in patties made from wheat flour only (No. 1). First limiting amino acid score was recorded for lysine. Addition of defatted soybean flour markedly increased the amino acids score of the patties.

\section{The computed protein efficiency ratio (C-PER):}

The computed protein efficiency ratio (C-PER) of different patties sample were lower than that of standard casein protein (PER $=2.50)$ as given in Table (8). The lower (C-PER) value was recorded in patties made from wheat flour only No. 1 (1.79), while the highest one was recorded in stuffed patties with cooked minced beef No. 4 (2.48). Generally, fortification of flour with deffated soybean, black rice, minced beef and spinach increased the C-PER of the produced patties. 
Table (7): ${ }^{*}$ Chemical scoring of the indispensable amino acids of patties sample.

\begin{tabular}{|l|c|c|c|c|c|c|c|}
\hline \multicolumn{1}{|c|}{$\begin{array}{c}\text { Indispensable } \\
\text { amino acids }\end{array}$} & No. 1 & No. 2 & No. 3 & No. 4 & No. 5 & No. 6 & $\begin{array}{c}\text { FAO/WHO } \\
\text { pattern } \\
\mathrm{g} / 16 \mathrm{~g} \mathrm{~N}\end{array}$ \\
\hline Leucine & 85.43 & 101.57 & 93.86 & 105.43 & 93.0 & 95.00 & 7.0 \\
Isoleucine & 72.0 & 91.75 & 87.25 & 102.50 & 85.75 & 86.50 & 4.0 \\
Lysine* & 52.73 & 68.18 & 45.45 & 80.18 & 44.36 & 58.36 & 5.5 \\
Methionine + cystine & 82.57 & 103.71 & 92.0 & 109.43 & 91.43 & 94.57 & 3.5 \\
Phenylalanine + tyrosnine & 99.0 & 119.17 & 110.17 & 128.17 & 109.50 & 111.0 & 6.0 \\
Threonine & 55.25 & 71.0 & 57.0 & 81.75 & 61.50 & 65.25 & 4.0 \\
Valine & 70.60 & 86.40 & 84.20 & 96.20 & 82.0 & 86.20 & 5.0 \\
Tryptophan & 94.0 & 123.0 & 120.0 & 143.0 & 116.0 & 119.0 & 1.0 \\
\hline
\end{tabular}

${ }^{*}$ Chemical scoring was calculated as a percentage of FAO/Who (1988) recommended amino acids.

No. 1 , No. 2, No. 3, ..... etc. were as given in Table (4).

Table (8): Computed protein efficiency ratio (C-PER) and biological value (BV) of patties sample.

\begin{tabular}{|c|c|c|}
\hline Patties sample & C-PER & B.V. \\
\hline No. 1 & 1.79 & 68.71 \\
No. 2 & 2.47 & 75.91 \\
No. 3 & 2.20 & 73.07 \\
No. 4 & 2.48 & 76.01 \\
No. 5 & 2.11 & 72.12 \\
No. 6 & 2.34 & 74.54 \\
Casein $^{*}$ & 2.50 & 76.23 \\
\hline
\end{tabular}

C-PER: Computed protein efficiency ratio

B.V.: Biological value

${ }^{*}$ C-PER and B.V. of casein according to (FAO/WHO pattern, 1988).

No. 1, No. 2, No. 3, .......etc. were as given in Table (4).

4. Biological value (B.V.):

The biological values of protein of different patties sample are shown in Table (8). Biological values are very useful parameter for evaluating the effect of processing on food protein quality (Abd Alla, 1981). The results revealed that, the stuffed patties with cooked minced beef had high biological value than other patties. Fortification of wheat flour to made patties increased the biological values of patties protein. These results may be related to the (C-PER) which was higher in stuffed patties with cooked minced beef than other patties.

\section{CONCLUSION}

From the obtained results, it can be concluded that, all prepared baked patties had high nutritive value. In such relation, the highest nutritive value was observed in patties made from wheat flour fortified with minced beef and patties made from wheat flour fortified with $5 \%$ defatted soybean flour. Furthermore, stuffing patties with minced beef and spinach may enhance the eating of patties quality and increased their iron contents. 


\section{REFERENCES}

Abd Alla, W.A.H. (1981). Effect of Cooking on Chemical and Biological Evaluation of Veal Meat and Liver. PH.D. Thesis, Fac. of Agric., Dept. Food Tech., Cairo University.

Abd El-Lateef, B.M. (2002). Bioavailability of folic acid in pan bread fortified with different sources of folic acid. Egypt. J. Food Sci., 30(2): 229-246.

Abd El-Rahim, E.A.; H.H.A. Khalaf and Ayman Ezzat (2001). Biotechnological studies on school children's Biscuits Enriched with Natural Sources of Iron and Zinc. Food Quality 2001, pp. 291-303.

Abd-Rabou, N.M.S. (1994). Production of Some Diabetic Dairy Products, Ph.D. Thesis, Food Tech. Dept., Fac. Agric., Ain-Shams Univ., Egypt.

Alsmeyer, R.H.; A.E. Cunningham and M.L. Happich (1974). Equations predict PER from amino acid analysis. Food Tech. 28(7): 34-40.

Alton, I. (2005). Iron deficiency anemia. Guide lines for adolescent nutrition services. Chap. (9): pp. 101-108. Stang. J. and M. Story (eds.).

Anonymous (1978-1980). National Nutrition Surveys. Arab Republic of Egypt. Office of Nutrition Aid.

A.O.A.C. (1990). Official Methods of Analysis, $15^{\text {th }}$ ed. Association of Official Agricultural Chemists, Washington D.C, USA.

Arora, S.M. (1983). Handbook of Bakery Products. Revised by Sisir Kumar Rath (Food Technologist) $36^{\text {th }}$ Publication on small scale industry.

Bach, S.B.; M. Hansen; K. Bukhare; M. Jensen; S. Sarensen; L. Kristensen; P. Purdon; L. Skilbsted and B. Sandstram (2003). Nonheme-iron absorption from a phytate-rich meal is increased by the addition of small amounts of pork meat. Am. J. Clin Nutr. 77: 173-179.

Bersamin, A. (2004). Nutritional and health Info-Sheet. Iron and Iron Deficiency Anemia. Available on the ANR Communication Service Web. htpp.www.anrcatalog. ucdavis.edu.

Bhushan, R. (1991). Amino acids and their derivatives. In: Handbook of TLC. Sherma, J. and Fried, B (eds.). Mercel Dekker Publishers, New York and Hong Kong, pp. 353-387.

Bothwell, T.H; R.W. Chariton; J.D. Cook and C.A. Finsh (1979). Iron metabolism in man, Oxford United Kingdom: Blackwell Scientific.

Cook, J.D.; M.B. Reddy; J. Burri; M.A. Juillenut and R.F. Hurrel (1997). The influence of different cereal grains on iron absorption form infant cereal foods. Am. J. Clin. Nutr. 65: 964-969.

Cross, H.R.; B.W. BVerry and L.H. Wells (1980). Effect of fat level and source on the chemical, sensory and cooking properties of ground beef patties, J. Food Sci., 45: 791-793.

El-Badawi, A.A.; S.M. Abu El-Matti; Madeha, A. Al-Shiwi; Afaf, A. Ahmed and A.S. Barakat (2003). Fortification of some patties with some plant sources Rich in Iron. Zagazig J. Agric. Res., Vol. 30: No. 51.

El-Demiry, Mervat, E. (2005). Preparation of high nutritive value bakery products fortified with soy meal and wheat white bran. Ph.D. Thesis in Food Tech. Dept. Faculty of Agric., Tanta Univ. Egypt.

El-Said Rhame, A..S. (2001). Designing Preparation and Evaluation of Diet for the Treatment of Iron Deficiency Anemia. M.Sc. Thesis in Home Economics, Faculty of Agric. Alex. Univ. Egypt.

FAO/WHO, Food and Agriculture Organization and World and Health Organization (1988). Energy and protein requirements. WHO Tech. Rept. Series No. 522 Genva. 
Farag, S.A.; A. El-Shirbeeny and E.N. Ashga (1996). Physicochemical studies for preparing quick-cooking rice by using gamma irradiation. Annals of Agric. Sci., Moshtohor, 34: 641-652.

Farrell, K.T. (1990). Spices, condiments and seasonings, $2^{\text {nd }}$ ed. p. 93-101. The AVI Publishing Co., Inc. Westport, Connection.

Gerrior, S. and L. Bente (2001). Food supply nutrients and dietary guidance, 1970-99. Food Review, 24(3), 39-46.

Gibson, R.S.; E.L. Ferguson and J. Lehrfeld (1998). Complementary foods for infant feeding in developing countries: Their nutrient adequacy and improvement. Eur.. J. Clin. Nutr., 52: 764-770.

Hamza, B.S. (1999). Improving Iron Absorption of Some Rich-Fiber Wheat Products. Ph.D. Thesis, Food Tech. Dept. Fac. of Agric., Cairo Univ., Egypt.

International Nutritional Anemia Consultative Group", (INACG) (1998). WHO, UNICEF. Guidelines for the use of iron supplements to prevent and treat iron deficiency anemia. Washington D.C. International Life Sciences Institute.

Infant, M.H.; G.H. Penu and A.S. Lopes (1979). Nutritive value of two different beans (Phaseolus volgaris) supplemented with methionine. J. Agric. Food Chem., 27: 965-968.

Kassab, H. (1999). Influences of adding some dietary volatile fatty acids and cooking on the chemical composition of fresh calves muscles. J. Agric. Res. Tanta Univ. 25(2).

Khalil, Mona, M. (2003). Effect of vitamin A on iron bioavailability in sponge cakes. J. Adv. Agric. Res. Vol. 8(2): 157-171.

Khalil, Mona, M. and M.A. Husein (2002). Chemical and biological studies on sponge cakes fortified with Guar flour or its protein isolate. J. Agric. Sci., Ain Shams Univ. Cairo. 11(1): 291-301.

Lund, E.K.; S.G. Wharf; S.J. Fairwheather-Tait and I.T. Jonhson (1999). Oral ferrous sulfate supplements increase the free radical-generating capacity of feces from healthy volunteers. Am. J. Clin. Nutr., 69: 250256.

Martinez-Navarrete, N.; M.M. Camacho; J. Martinez-Lahuerta, J. MartinezMonzo and P. Fito (2002). Iron deficiency and iron fortified foods. A review. Food Research International, 35: 225-231.

Mendoza, C.; J. Peerson; K. Brown and B. Lonnerdal (2004). Effect of a micronutrient fortificant mixture and 2 amounts of calcium on iron and zinc absorption from a processed food supplemented. Am. J. Clin. Nutr., 79: 244-250.

Miligi, A.; I.R. Zein; A.A. Salama and F.A. El-Zahraa (2000). Effect of blanching, packaging and frozen storage on some vitamins and minerals content of spinach and taro. J. Agric. Res. Tanta Univ. 26(2).

Miller, M.L. (1967). Determination of the tryptophan content of feeding stuffs with particular reference to cereals. J. Sci. Food Agric., 18: 381.

Nour, A.Y.M.; M.L. Thonney and J.R. Stouffer (1983). Muscle mineral concentrations predicator of taste panel sensory attributes of beef. J. Food Sci., 48: 1170-1171. 
Park, S.; M.S. Brewer; J. Novakofski; P.J. Bechtel and F.K. Mekeith (1996). Process and characteristics for a surimi-like material made form beef or park. J. Food Sci. 61(2): 422-425.

Pellett, P.L. and V.R. Young (1980). Nutritional evaluation of food proteins. Food and Nutritional Bulletin Supplement 4. The United Nations University, Tokyo, Japan.

Ree, J.M. and E.R. Monsen (1973). Absorption of fortification iron by the rat: Comparison of type and level of iron incorporated into mixed graincereal. J. Agric. Food Chem. 21: 913-917.

Renzo, D. (1975). Bakery products yeast leavened. Noyes Data Corporation. London, England.

Sadasivam, S. and A. Manickam (1992). Determination of total sugars, reducing sugars and amino acids, Agriculture Science, Wiely Eastern Limited, New Delhi, India, pp. 6 and 40.

Spadaro, V. and T. Keeton (1996). Qualitative and quantitative textural assessment of cooked ground beef patties. J. Food Sci. 61(1): 235240.

Steel, R.G. and J.H. Torrie (1980). Principles and procedures of statistics. MgGraw-Hill (Publ.). New York, NY.

Swanson, C.A. (2003). Iron intake and regulation: Implications for iron deficiency and iron overload. Alcohol, 30: 99-102.

UNICEF (1991). The state of Egypt children. National Workshop Preparation For Country Paper on A Nutrition of the International Conference of Nutrition.

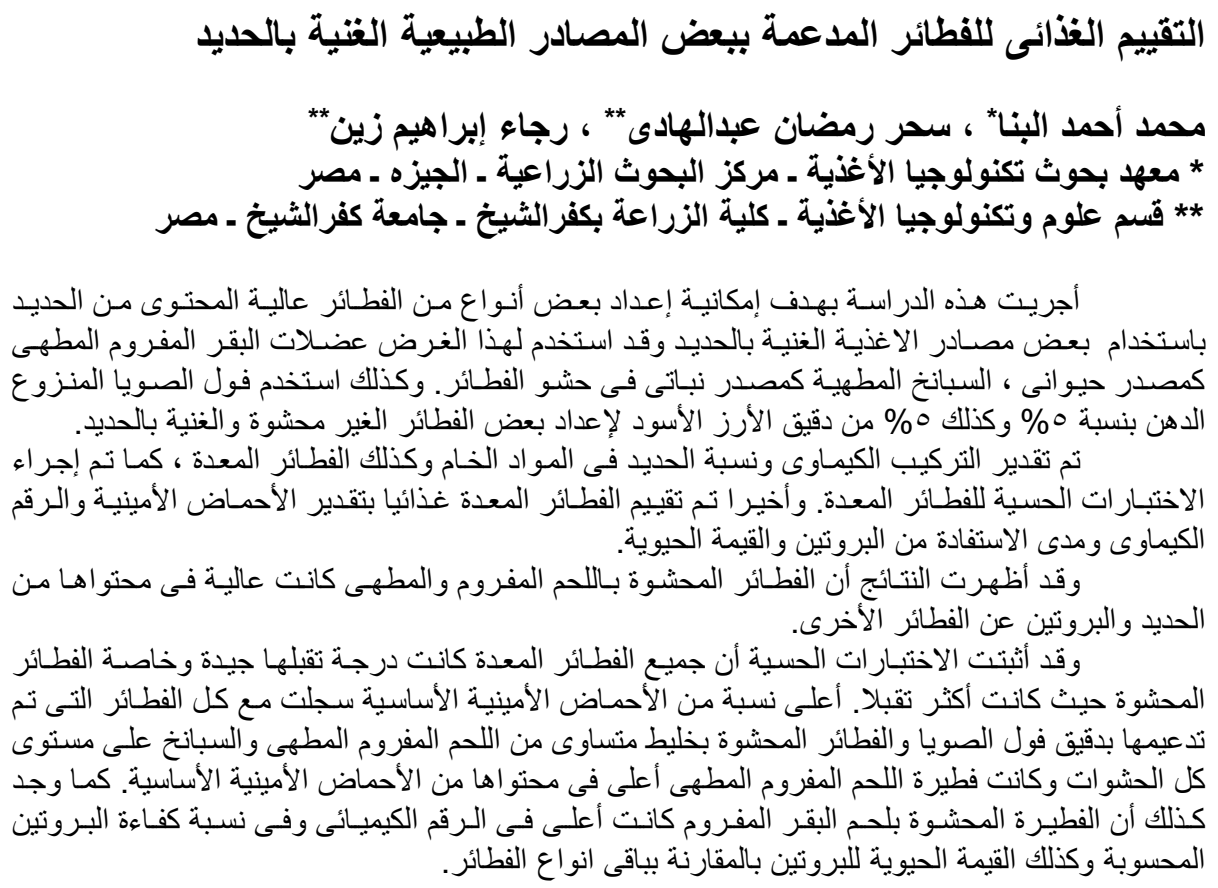

